\title{
ПОДВИЖНОСТЬ СИЛИКАТОВ, ПОКАЗАТЕЛИ ПЛОДОРОДИЯ ДЕРНОВО-ПОДЗОЛИСТОЙ ПОЧВЫ, БИОАККУМУЛЯЦИЯ КРЕМНИЯ И ПРОДУКТИВНОСТЬ СЕЛЬСКОХОЗЯЙСТВЕННЫХ КУЛЬТУР ПОД ДЕЙСТВИЕМ ЦЕОЛИТА
}

\author{
А.В. КОЗЛОВ 1 Ф, А.Х. КУЛИКОВА², И.П. УРОМОВА ${ }^{1}$
}

В современных условиях организации земледелия актуальны испытания кремнийсодержащих природных материалов, в том числе цеолитов, которые оказывают оструктуривающее и влагоудерживающее действие на почву, оптимизируют условия для развития агрономически ценных микроорганизмов, пополняют почвенный раствор доступными формами калия, фосфора и микроэлементов, проявляют активность в отношении избыточной кислотности почв. Обеспеченность кремнием сельскохозяйственных культур позволяет повышать их адаптацию к стрессовым факторам агроэкотопа, увеличивать продуктивность и качественные характеристики урожая. Впервые в условиях дерново-подзолистых почв Нижегородской области мы установили положительное воздействие разных доз цеолитовой породы Хотынецкого месторождения на эффективное плодородие дерново-подзолистой легкосуглинистой почвы и содержание в ней биологически активного кремния. Определено влияние породы на накопление различных кремниевых соединений в надземной биомассе сельскохозяйственных культур, выявлено повышение их урожайности за счет действия цеолита и установлена оптимизация показателей качества основной части урожая. Цель работы - определение подвижности кремния в дерново-подзолистой легкосуглинистой почве, оценка ее физико-химических и агрохимических свойств, а также выявление особенностей биоаккумуляции различных кремниевых соединений надземной фитомассой сельскохозяйственных культур в зависимости от дозы цеолитовой породы. Исследования проводили в 2015-2017 годах на сортах сельскохозяйственных культур, районированных по Волго-Вятскому региону: озимой пшенице (Triticum aestivum L.) сорта Московская 39 и яровой пшенице Курская 2038, озимой ржи (Secale cereale L.) Валдай, ячмене (Hordeum vulgare L.) Велес, горохе посевном (Pisum sativum L.) Чишминский 95 и картофеле (Solarium tuberosum L.) Ред Скарлет. Схема опытов включала контрольный вариант, а также внесение цеолита Хотынецкого месторождения (ООО «Алсико-Ресурс», Россия) в почву в дозах 3, 6 и 12 т/га. Породу вносили однократно вручную в летний период 2014 года. Почва - дерново-подзолистая, среднедерновая неглубокооподзоленная неоглеенная легкосуглинистая, сформированная на покровном суглинке. Растения убирали в фазу полной спелости (у зерновых культур), а также в фазу начала (у гороха) и конца (у картофеля) усыхания ботвы. В надземной фитомассе всех культур определяли содержание органических, растворимых минеральных, нерастворимых полимерных и общих соединений кремния. Почву отбирали в день уборки урожая с пяти точек делянки методом конверта и оценивали содержание подвижных соединений кремния. Также в образцах почвы определяли актуальную, обменную кислотность, гидролитическую кислотность, содержание обменных соединений кальция и магния, количество обменных форм калия, содержание подвижных соединений фосфора по Кирсанову и гумуса по Тюрину. Применение цеолитовой породы в дозе 12 т/га способствовало увеличению содержания в почве водорастворимых форм кремния на $143 \%(p<0,05)$, кислоторастворимых - в 2 раза. Использование мелиоративных доз цеолита в течение трех лет способствовало достоверному $($ p $<0,05)$ снижению обменной кислотности почвы на 0,5 ед. pH, гидролитической кислотности - на 0,33 мг-экв/100 г, значительному увеличению содержания обменных соединений кальция и магния (соответственно на 4,4 и 10,8 мг-экв/100 г), а также статистически значимому (р $<0,05)$ повышению количества подвижных соединений фосфора (на $43 \%$ ) и калия (на $46 \%$ ) относительно контрольных значений. Накопление кремния в фитомассе урожая зависело от культуры и у всех зерновых было выше в побочной продукции, чем в основной. Применение цеолита приводило к повышению усвоения кремния из почвы, в особенности у растений-кремнефилов. Под действием материала в зерне яровой пшеницы, ячменя и гороха накопление общего кремния превышало контрольные значения соответственно в 1,8, 2,3 и в 3,6 раза $($ p < 0,05). Применение цеолита активировало образование органических и минеральных растворимых форм элемента в зерновой части урожая, но не способствовало накоплению нерастворимых соединений кремния в фитомассе. Урожайность основной продукции озимой пшеницы увеличивалась на 0,19 т/га, ячменя - на 0,98 т/га, гороха посевного - на 0,24 т/га, картофеля - на 8,6 т/га, яровой пшеницы - на 0,92 т/га, озимой ржи - на 0,39 т/га $($ р $<0,05)$. Наилучший эффект в отношении всех культур оказывали дозы цеолита 6 и 12 т/га, при этом соотношение основной и побочной продукции культур сужалось в сторону зерновой (клубневой) 
части урожая. Оптимизация кремниевого питания культурных растений и подвижности элемента в почве за счет внесения высоких доз цеолита положительно отражалась на качестве основной продукции. Накопление сырой клейковины в зерне озимой и яровой пшеницы достигало соответственно 35,3 и $31,1 \%$, а накопление белка в зерне ячменя и гороха $-12,7$ и 20,6 \%. Повышение качества клубней картофеля под действием породы выражалось в увеличении содержания витамина С (до 22,2 мг\%) и повышении накопления крахмала (до 16,3 \%). Следовательно, использование цеолита в качестве удобрительного и мелиоративного материала агрономически целесообразно и необходимо в условиях дерново-подзолистых почв.

Ключевые слова: цеолит, кремний, биоаккумуляция, сельскохозяйственные культуры, фитомасса, продуктивность, качество урожая, почва, содержание кремния, подвижность кремния.

Урожайность сельскохозяйственных культур в значительной степени зависит от обеспеченности почв мобильными формами макро- и микроэлементов, агрофизических свойств пахотного горизонта, а также от кислотно-основного состояния почвенного раствора $(1,2)$. Помимо этого, существует ряд внешних динамических факторов агроэкотопа, потенциально влияющих на реализацию агробиологического потенциала любой культуры. К ним относится динамика содержания свободной воды в корнеобитаемом слое почвы, наличие в ней легкорастворимых солей, соединений алюминия и иных фитотоксикантов, фитосанитарный фон и температурные условия местности $(3,4)$. Повышение адаптационного потенциала сельскохозяйственных культур к таким параметрам окружающей среды - одна из первоочередных задач при оптимизации функционирования агроэкосистем $(5,6)$.

В условиях современного земледелия необходим поиск результативных и экологически приемлемых способов повышения продуктивности культурных растений, которые обеспечат поддержание эффективного плодородия почвы, ее кислотно-основного режима, гармоничную активизацию сапротрофной и азотфиксирующей ассоциаций микроорганизмов, а также обладают пролонгированным действием. К таким способам относится применение природных высококремнистых пород различного генезиса в качестве удобрений и мелиорантов (7-9). Указанные материалы содержат значительное количество доступных для растений элементов питания и мелиоративных компонентов, в том числе соединений фосфора, калия и кремния, а также кальций-магниевый ионообменный комплекс (10-12).

Кремний - один из основных элементов, усваиваемых растительным организмом, однако его участие в биохимических и физиологических процессах остается малоизученным (13-15). В настоящее время установлено, что соединения кремния участвуют в утолщении клеток эпидермальных тканей, стимулируют надземный рост и активность корневой системы, а также повышают общую устойчивость растительного организма к абиотическим стрессам (экологический и солевой факторы, потеря тургора от пересыхания и перегревания), поражению болезнями и вредителями (16-18).

Растения поглощают кремний из почвенного раствора в виде ионов $\left(\mathrm{SiO}_{3}{ }^{2-}\right.$ и $\left.\mathrm{SiO}_{4}{ }^{4-}\right)$ и монокремниевых кислот $\left(\mathrm{H}_{2} \mathrm{SiO}_{3}\right.$ и $\left.\mathrm{H}_{4} \mathrm{SiO}_{4}\right)$, после чего эти соединения превращаются в кремнегель $\left(\mathrm{SiO}_{2} \cdot \mathrm{nH}_{2} \mathrm{O}\right)$ в клеточной жидкости. Далее происходит биохимическое связывание с полимерными компонентами клетки (полипептидами, белками и сложными углеводами), аккумуляция в клеточных стенках и в покровных тканях (эпидермис листьев и корней), а также накопление в фитолитах. Выявлено, что двойной кутикулярный слой, представляющий собой кремнецеллюлозную мембрану, образуется при формировании покровных тканей растения $(19,20)$.

Установлено $(21,22)$, что в растительной клетке кремний представлен ортокремниевыми эфирами белков, липидов и фосфолипидов, про- 
стых аминокислот, оксиаминокислот, полисахаридов и лигнина. Количество кремния, связанного в органических структурах, составляет не менее $40 \%$ от его общего содержания. Как правило, преобладающая форма органически связанного кремния - полимерная, ее количество достигает 80$85 \%$. В частности, в злаках до $60 \%$ кремния связано с полипептидами и белками, более $11 \%$ - с липидами и фосфолипидами, около $9 \%$ - с клетчаткой и гемицеллюлозой, не более $5 \%$ - с пектином, менее $3 \%$ с лигнином.

Предполагается, что эфирные соединения кремния, образующие в клеточных стенках растений связи с полисахаридами (пектином и клетчаткой), а также с белками и лигнином, формируют термоизолирующие структуры и, как следствие, определяют морозостойкость растений, оптимизируют перезимовку и ускоряют весеннюю акклиматизацию озимых и многолетних культур (23-25). В структуре клетчатки и гемицеллюлозы кремний выступает в качестве сшивающего агента, образуя силоксановые связи (мостики) между сахарными остатками $(26,27)$. Вследствие образования таких связей повышается прочность соломины зерновых культур, а также устойчивость злаковых к полеганию и засушливым условиям местности (28-29). Ряд авторов объясняют это явление повышением содержания общего и органически связанного кремния в фитомассе растений в течение вегетации $(21,30,31)$.

Полимерные вещества, содержащие кремний, служат компонентами коронарных клеток корневого чехлика и выделяемых корневыми волосками слизей. Последние исследования подтверждают, что внешняя оптимизация кремниевого питания растений способствует увеличению накопления биомассы корней, их ветвистости, общей и адсорбирующей рабочей поверхности, а также улучшает корневое дыхание растений (32-34). Применение кремнийсодержащих удобрений и силатрановых стимуляторов роста в агроценозах повышает общий адаптационный потенциал сельскохозяйственных культур при увеличенном содержании фитотоксичных веществ в почве, способствует снижению восприимчивости к засухе и росту устойчивости к окислительным и солевым стрессам (35-37). Кроме того, бездефицитный баланс подвижного кремния в почвах нормализует выработку цитокининов и активизирует образование фитоалексинов в клетках растений $(17,18)$, что способствует усилению их естественной сопротивляемости по отношению к нематодам, гифам фитопатогенных грибов, физиологическим выделениям бактерий и действию других корневых вредителей (38-40). Эти факты могут определять более эффективную реализацию агробиологического потенциала культуры и ее сорта в конкретных почвенноклиматических условиях под влиянием рассматриваемых факторов.

В целом нужно отметить, что и другие авторы (41-43) указывают на множественное положительное действие кремния и его соединений в системе почва-растение. Однако в научной литературе недостаточно сведений о запасах мобильного кремния в почвах, мелиоративном эффекте высококремнистых пород в отношении избыточной кислотности почв, а также об особенностях биоаккумуляции силикатов в культурных растениях (44, 45). В частности, крайне мало данных о влиянии мелиоративных высококремнистых материалов на кислотно-основной баланс почв, что в условиях сельского хозяйства нашей страны рассматривается как острая и актуальная проблема.

В настоящее время в России закисление пахотных земель приняло практически повсеместный характер (46), причем это явление касается не только генетически выщелоченных и обедненных почв, в частности почв 
подзолистого ряда Нечерноземной полосы страны (47). Одна из причин такой ситуации - нерациональное или крайне недостаточное применение химических мелиорантов и органических удобрений, которые способствуют оптимизации кислотности почв (48). Ряд исследователей подчеркивают актуальность изучения высококремнистых пород в качестве альтернативы традиционным мелиорантам $(36,37,45)$. Кроме того, фракционный состав соединений кремния в сельскохозяйственных растениях - один из самых мало затрагиваемых аспектов физиологии, который важен для развития представлений о распределении этих веществ в растительной клетке и о формировании физиологических механизмов адаптации к неблагоприятным условиям агроэкотопа. Решение вышеуказанных вопросов необходимо для понимания механизмов участия кремния в системе почва-растение и, как следствие, определяет интерес к дальнейшему изучению эффектов от применения кремнийсодержащих веществ в агроэкосистемах.

Впервые в условиях дерново-подзолистых почв Нижегородской области мы установили положительное влияние различных доз цеолитовой породы Хотынецкого месторождения на эффективное плодородие дерново-подзолистой легкосуглинистой почвы и содержание в ней биологически активного кремния. Охарактеризовано влияние породы на накопление различных кремниевых соединений в надземной биомассе сельскохозяйственных культур. Показано повышение их урожайности за счет действия цеолита и установлена оптимизация показателей качества основной части урожая.

Цель работы - определение подвижности кремния в дерновоподзолистой легкосуглинистой почве, оценка ее физико-химических и агрохимических свойств, а также выявление особенностей биоаккумуляции различных кремниевых соединений надземной фитомассой сельскохозяйственных культур в зависимости от дозы цеолитовой породы как высококремнистого мелиоративного материала.

Методика. Исследования проводили в 2015-2017 годах на сортах сельскохозяйственных культур, районированных по Волго-Вятскому региону (49): озимой пшенице (Triticum aestivum L.) сорта Московская 39 и яровой пшенице Курская 2038, озимой ржи (Secale cereale L.) Валдай, ячмене (Hordeum vulgare L.) Велес, горохе посевном (Pisum sativum L.) Чишминский 95 и картофеле (Solarium tuberosum L.) Ред Скарлет. Каждый год результаты исследования учитывались по двум культурам: в 2015 году это были озимая пшеница и картофель, в 2016 году - ячмень и яровая пшеница, в 2017 году - горох посевной и озимая рожь.

Микроделяночные опыты с культурами закладывали в 2014 году по общепринятым в агрономической практике правилам (50) в полевых условиях предприятия ООО «Элитхоз» (д. Филипповское, Борской муниципальный р-н, Нижегородская обл., 56³1'13.00"N 4406'57.37"Е). Размещение делянок $\left(1 \mathrm{M}^{2}\right)$ в опытах рандомизированное, повторность 4-кратная. Схема опытов включала вариант без использования удобрений и мелиорантов (контроль), а также внесение цеолита в почву в дозах 3, 6 и 12 т/га (соответственно варианты Ц1, Ц2 и Ц3). Породу вносили в почву однократно, вручную, в летний период 2014 года при разбивке участка на делянки.

Использованный в работе цеолит Хотынецкого месторождения (ООО «Алсико-Ресурс», Россия) более чем на 37 \% состава был представлен клиноптилолитом, а также содержал свыше $15 \%$ опал-кристобалита, около $11 \%$ гидрослюд, $10 \%$ тонкозернистого кварца и 8-10\% монтмориллонита (51). В валовом составе цеолитовой породы содержались $\mathrm{SiO}_{2}$ (56,6 \%), $\mathrm{CaO}(13,3 \%), \mathrm{MgO}(1,90 \%), \mathrm{P}_{2} \mathrm{O}_{5}(0,23 \%), \mathrm{K}_{2} \mathrm{O}(1,82 \%), \mathrm{Na}_{2} \mathrm{O}$ 
$(0,23 \%), \mathrm{SO}_{3}(0,13 \%), \mathrm{Al}_{2} \mathrm{O}_{3}(10,41 \%), \mathrm{FeO}+\mathrm{Fe}_{2} \mathrm{O}_{3}(3,87 \%)$ и другие элементы.

Почва опытного поля - дерново-подзолистая среднедерновая неглубокооподзоленная неоглеенная легкосуглинистая, сформированная на покровном суглинке. На момент закладки опыта почва характеризовалась среднекислой реакцией ( 2,83 мг-экв/100 г, средним содержанием обменных соединений кальция $(5,10$ мг-экв/100 г) и магния $(1,17$ мг-эКв/100 г), средней степенью насыщенности основаниями (Vs $69 \%)$, низким содержанием гумуса $(1,21 \%)$, средней обеспеченностью подвижными соединениями фосфора (86 мг/кг) и калия (110 мг/кг) по Кирсанову, а также средним дефицитом в балансе актуальных (16 мг/кг) и потенциальных (213 мг/кг) соединений кремния по Матыченкову.

Растения убирали в фазу полной спелости (у зерновых культур), а также в фазу начала (у гороха) и конца (у картофеля) усыхания ботвы. Урожайность (биомассу) надземной части зерновых культур, ботвы и клубней картофеля определяли в поле в день уборки урожая, урожайность (биомассу) зерна - в лабораторных условиях. В надземной фитомассе всех культур определяли содержание органических, растворимых минеральных, нерастворимых полимерных и общих соединений кремния; их экстракцию осуществляли по методу М.П. Колесникова (21) со спектрофотометрическим окончанием по методу А.Г. Барсуковой (52) (спектрофотометр ПЭ5400 ВИ, ООО «Экросхим», Россия). В зерне озимой и яровой пшеницы также оценивали содержание сырой клейковины методом отмывания по ГОСТ Р 54478-2011 (М., 2012); в зерне ячменя и гороха - количество белка посредством мокрого озоления растительной массы и отгонки белкового азота в виде аммиака по микрометоду Кьельдаля с последующим пересчетом на содержание белка (52); в клубнях картофеля - содержание крахмала поляриметрически (52) и количество витамина С флуориметрически на анализаторе ФЛЮОРАТ-02-5М (ГК «Люмэкс», Россия) по ФР.1.31.2011.09380 (53).

Почву отбирали в день уборки урожая с пяти точек делянки методом конверта, подготавливали к анализу и определяли содержание подвижных соединений кремния (растворимых в дистиллированной воде и в 0,1 н. растворе $\mathrm{HCl}$ ) спектрофотометрическими методами В.В. Матыченкова с соавт. (54) (спектрофотометр ПЭ-5400 ВИ, ООО «Экросхим», Россия). Также в образцах почвы определяли актуальную, обменную кислотность потенциометрическим методом (рН-метр-милливольтметр МАРК903, ООО «ВЗОР», Россия), гидролитическую кислотность - титриметрией (ГОСТ 26212-91. М., 1992), содержание обменных соединений кальция и магния - трилонометрией (ГОСТ 26487-85. М., 1985), количество обменных форм калия - методом пламенной фотометрии (ГОСТ Р 546502011. М., 2019), содержание подвижных соединений фосфора по Кирсанову (ГОСТ Р 54650-2011) и гумуса по Тюрину (ГОСТ 26213-91. М., 1992) спектрофотометрическими методами (спектрофотометр ПЭ-5400 ВИ) (55).

Химические анализы почвы и растений выполняли в 2015-2017 годах. Полученные данные обрабатывали методами вариационного и дисперсионного анализа (50) в программном пакете Microsoft Office Excel 2007. Рассчитывали средние арифметические значения и стандартные отклонения $(M \pm \mathrm{SD})$, коэффициент вариации $(C v, \%)$, ошибку выборочной средней ( ХХсред., \%); наименьшую существенную разность $\left(\mathrm{HCP}_{05}\right)$ и критерий Фишера $\left(F_{f}\right)$ при статистическом уровне значимости $\mathrm{p}<0,05$ (теоретический критерий Фишера $F_{t}$ при $n l=3$ и р $<0,05$ равен 3,86$)$. 
Результаты. Катионообменный комплекс использованной породы включал значительное количество обменных соединений кремния (900 мгэкв/100 г $\left.\mathrm{SiO}_{3}{ }^{2-}\right)$, кальция (480 $\mathrm{Ca}^{2+}$ мг-экв/100 г) и магния $\left(\mathrm{Mg}^{2+} 160\right.$ мгэкв/100 г), а также обменные соединения фосфора (до 26 мг-экв/100 г) и калия (до 25 мг-экв/100 г), что обусловливало питательную ценность материала для агрофитоценозов. Относительно высокая растворимость и содержание в цеолите обменных форм основных катионов, а также биогенных элементов определяли его податливость к постепенному химическому разложению в почве и биохимической деструкции почвообитающими микроорганизмами, что способно оказывать положительное влияние на агрохимические и агрофизические свойства пахотного слоя.

В опытах было установлено положительное влияние цеолита на содержание в почве подвижных соединений кремния (табл. 1). В частности, накопление водорастворимых кремниевых веществ (монокремниевые кислоты и силикат-анионы) достоверно $(\mathrm{p}<0,05)$ достигало максимума в 2016 году (до 40 мг/кг почвы), а эффективность применения цеолита - в 2017 году, когда увеличение показателя сверх выноса элемента культурами варьировало от 82 до 209 \% в зависимости от дозы породы.

1. Содержание подвижных соединений кремния в дерново-подзолистой легкосуглинистой почве при применении цеолита Хотынецкого месторождения в разных дозах (ООО «Элитхоз», д. Филипповское, Борской муниципальный р-н, Нижегородская обл.)

\begin{tabular}{|c|c|c|c|c|c|c|c|}
\hline \multirow{3}{*}{ Вариант } & \multicolumn{6}{|c|}{ Содержания подвижных соединений кремния, мг/кг почвы } & \multirow{3}{*}{$\begin{array}{l}\text { В среднем } \\
\text { за } 3 \text { года }\end{array}$} \\
\hline & \multicolumn{2}{|c|}{2015 год } & \multicolumn{2}{|c|}{2016 год } & \multicolumn{2}{|c|}{2017 год } & \\
\hline & $M \pm \mathrm{SD}$ & $C v, \%$ & $M \pm \mathrm{SD}$ & $C v, \%$ & $M \pm S D$ & $C v, \%$ & \\
\hline \multicolumn{8}{|c|}{ Водорастворимы е формы кремния } \\
\hline Контроль & $16 \pm 2$ & 22 & $14 \pm 1$ & 18 & $11 \pm 1$ & 12 & 14 \\
\hline$Ц_{1}, 3$ т/га & $22 \pm 1$ & 8 & $25 \pm 2$ & 14 & $20 \pm 1$ & 12 & 22 \\
\hline$Ц_{2}, 6$ т/га & $24 \pm 1$ & 2 & $33 \pm 1$ & 7 & $29 \pm 2$ & 12 & 29 \\
\hline Ц3, 12 т/га & $29 \pm 1$ & 6 & $40 \pm 1$ & 7 & $34 \pm 2$ & 13 & 34 \\
\hline$F_{f}$ & 24,68 & & 363,98 & & 41,92 & & \\
\hline \multicolumn{8}{|c|}{ Кислоторастворимы е формы кремния } \\
\hline Контроль & $213 \pm 9$ & 8 & $201 \pm 4$ & 4 & $206 \pm 5$ & 5 & 207 \\
\hline$Ц_{1}, 3$ т/га & $281 \pm 12$ & 8 & $306 \pm 3$ & 2 & $292 \pm 5$ & 4 & 293 \\
\hline Ц2, 6 т/га & $330 \pm 21$ & 13 & $399 \pm 7$ & 4 & $376 \pm 7$ & 4 & 368 \\
\hline Ц3, 12 т/га & $409 \pm 26$ & 13 & $429 \pm 4$ & 2 & $402 \pm 6$ & 3 & 413 \\
\hline$F_{f}$ & 15,56 & & 371,65 & & 330,94 & & \\
\hline При м еч & - крит & H & & & & & \\
\hline
\end{tabular}

В 2015 и 2016 годах применение минимальной дозы цеолита $(3$ т/га) статистически значимо $(\mathrm{p}<0,05)$ способствовало повышению содержания в почве легкоподвижных кремниевых веществ соответственно на 38 и $79 \%$ относительно контрольных значений, а в среднем за 3 года показатель увеличился на 57-143\% в зависимости от дозы. На кислоторастворимые формы кремния внесение различных доз материала также оказывало достоверное, но менее выраженное воздействие. Например, увеличение дозы цеолита в 2 раза дополнительно повышало ( $\mathrm{p}<0,05)$ содержание кремниевых веществ в почве на 23-47 \% в зависимости от года исследования. В целом наиболее выраженный статистически обоснованный эффект был установлен в 2016 году, когда показатель увеличился $(\mathrm{p}<0,05)$ на $52-113 \%$ от контрольного значения. В среднем по годам внесение в почву 12 т/га породы способствовало повышению содержания кислоторастворимых форм кремния практически в 2 раза $(\mathrm{p}<0,05)$.

Подобные закономерности были обусловлены внесением в почву значительного количества водорастворимых соединений кремния в виде силикатов и мономеров кремниевых кислот (56), чему способствовало достаточное количество осадков, активно участвующих в растворении веще- 
ства породы. Погодные условия 2015 года характеризовались несущественным количеством осадков, сам год в целом был более жарким по сравнению со средними климатическими нормами региона (гидротермический коэффициент ГТК в летние месяцы варьировал в пределах 0,9-1,0). В 2016 году, наоборот, не отмечали дефицит осадков, температура воздуха колебалась в пределах нормы с ее небольшим превышением в августе $(\Gamma \mathrm{TK}=1,0-1,1)$. Метеоусловия 2017 года характеризовались обильным количеством осадков весной и в первой половине лета, температура воздуха находилась в пределах среднегодовых норм в течение летнего сезона $($ ГТК $=1,1-1,2)$.

Полученные данные согласуются с результатами других авторов. В частности, сообщалось, что при внесении в почву 3 т/га аморфного кремнезема содержание водорастворимых форм кремния увеличивалось на 7,3 мг/кг (36 \%) в черноземе обыкновенном и на 11,9 мг/кг (73\%) в каштановой почве $(19,51)$. Однако содержание в этих почвах кислоторастворимых соединений кремния возрастало менее выраженно - соответственно на 15,5 мг/кг (22\%) и на 19,7 мг/кг (66 \%). Причиной более существенного увеличения содержания подвижных форм кремния в дерново-подзолистой почве могла быть, с одной стороны, низкая почвенная буферность, которая не препятствует высвобождению в жидкую фазу растворенных соединений, с другой - средняя кислотность верхнего почвенного слоя, активно способствующая химической минерализации вещества мелиорантов и высвобождению в почвенный раствор их растворимых компонентов $(1,11)$.

Применение цеолита в мелиоративных дозах приводило не только к пополнению почвенного раствора подвижными соединениями кремния, но и к снижению кислотности почвы, а также к накоплению важнейших биогенных элементов - кальция и магния (табл. 2).

2. Основные показатели плодородия дерново-подзолистой легкосуглинистой почвы при применении цеолита Хотынецкого месторождения в разных дозах (ООО «Элитхоз», д. Филипповское, Борской муниципальный р-н, Нижегородская обл.)

\begin{tabular}{|c|c|c|c|c|c|c|c|}
\hline \multirow{3}{*}{ Вариант } & \multicolumn{6}{|c|}{ Показатели плодородия почвы } & \multirow{3}{*}{$\begin{array}{l}\text { В среднем } \\
\text { за } 3 \text { года }\end{array}$} \\
\hline & \multicolumn{2}{|c|}{2015 год } & \multicolumn{2}{|c|}{2016 год } & \multicolumn{2}{|c|}{2017 год } & \\
\hline & $M \pm \mathrm{SD}$ & $C v, \%$ & $M \pm \mathrm{SD}$ & $C v, \%$ & $M \pm \mathrm{SD}$ & $C v, \%$ & \\
\hline \multicolumn{8}{|c|}{ Акт уальная к ислотность $($ рНн2O), ед. } \\
\hline Контроль & $5,88 \pm 0,13$ & 4 & $5,96 \pm 0,07$ & 2 & $5,92 \pm 0,07$ & 2 & 5,92 \\
\hline Ц1, 3 т/га & $6,54 \pm 0,10$ & 3 & $6,66 \pm 0,12$ & 4 & $6,71 \pm 0,09$ & 3 & 6,64 \\
\hline Ц2, 6 т/га & $6,97 \pm 0,16$ & 4 & $7,03 \pm 0,07$ & 2 & $7,09 \pm 0,02$ & 1 & 7,03 \\
\hline Ц3, 12 т/га & $6,93 \pm 0,05$ & 1 & $6,99 \pm 0,12$ & 3 & $7,04 \pm 0,06$ & 2 & 6,99 \\
\hline Ff & 27,81 & & 21,69 & & 128,45 & & \\
\hline \multicolumn{8}{|c|}{ Об менн а я } \\
\hline Контроль & $4,81 \pm 0,04$ & 2 & $4,90 \pm 0,05$ & 2 & $4,86 \pm 0,09$ & 4 & 4,86 \\
\hline Ц1, 3 т/га & $5,04 \pm 0,07$ & 3 & $5,17 \pm 0,01$ & 1 & $5,27 \pm 0,05$ & 2 & 5,16 \\
\hline Ц2, 6 т/га & $5,21 \pm 0,14$ & 5 & $5,31 \pm 0,02$ & 1 & $5,49 \pm 0,11$ & 4 & 5,34 \\
\hline Ц3, 12 т/га & $5,16 \pm 0,13$ & 5 & $5,28 \pm 0,03$ & 1 & $5,36 \pm 0,08$ & 3 & 5,27 \\
\hline$F_{f}$ & 2,65 & & 43,76 & & 10,18 & & \\
\hline \multicolumn{8}{|c|}{ Ги д рол и т и ч е с к а я к и с лот н ость (НГ), мГ-эКв/100 г } \\
\hline Контроль & $2,84 \pm 0,02$ & 1 & $2,75 \pm 0,02$ & 2 & $2,82 \pm 0,02$ & 2 & 2,80 \\
\hline Ц1, 3 т/га & $2,76 \pm 0,02$ & 2 & $2,61 \pm 0,02$ & 2 & $2,67 \pm 0,03$ & 2 & 2,68 \\
\hline Ц2, 6 т/га & $2,60 \pm 0,03$ & 2 & $2,49 \pm 0,03$ & 3 & $2,55 \pm 0,02$ & 2 & 2,55 \\
\hline Ц3, 12 т/га & $2,52 \pm 0,01$ & 1 & $2,41 \pm 0,03$ & 3 & $2,49 \pm 0,04$ & 3 & 2,47 \\
\hline$F_{f}$ & 55,16 & & 24,43 & & 27,51 & & \\
\hline \multicolumn{3}{|c|}{ Содержание обменных } & \multicolumn{5}{|c|}{ с о ед и не н и й к альц ия $\left(\mathrm{Ca}^{++}\right)$, мг-ЭКв/100 г } \\
\hline Контроль & $5,12 \pm 0,04$ & 2 & $5,23 \pm 0,05$ & 2 & $5,19 \pm 0,11$ & 4 & 5,18 \\
\hline$Ц_{1}, 3$ т/га & $6,43 \pm 0,05$ & 1 & $8,56 \pm 0,05$ & 1 & $9,11 \pm 0,12$ & 2 & 8,03 \\
\hline Ц2, 6 т/га & $10,30 \pm 0,02$ & 2 & $13,67 \pm 0,07$ & 1 & $15,83 \pm 0,28$ & 4 & 13,27 \\
\hline Ц3, 12 т/га & $18,04 \pm 0,03$ & 1 & $23,89 \pm 0,13$ & 2 & $26,60 \pm 0,14$ & 1 & 22,84 \\
\hline$F_{f}$ & 298,80 & & 341,86 & & 614,74 & & \\
\hline
\end{tabular}




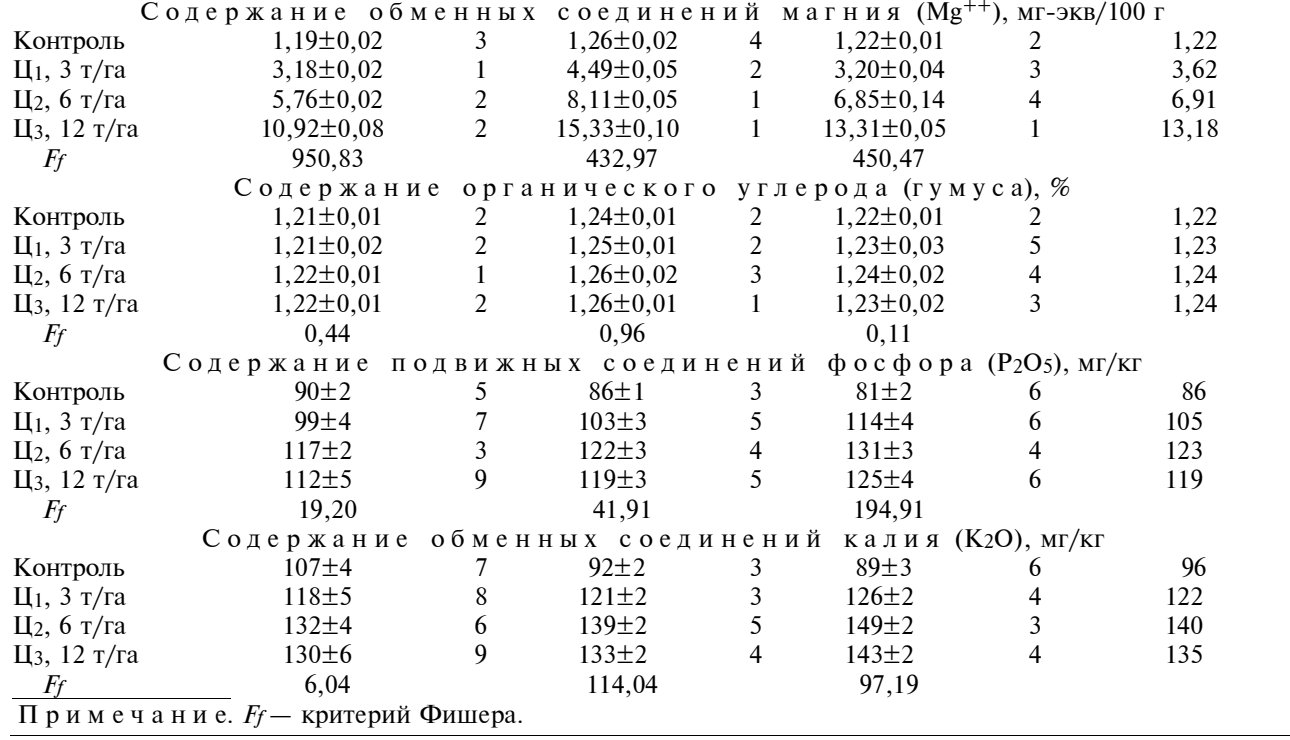

За три года эксперимента на фоне цеолитовой породы актуальная кислотность почвы статистически значимо $(\mathrm{p}<0,05)$ снизилась более чем 1 ед., а обменная кислотность - почти на 0,5 ед. Такое кислотноосновное состояние почвенного раствора было обусловлено достоверным $(\mathrm{p}<0,05)$ уменышением гидролитической кислотности (на 0,33 мг-эКв/100 г) за счет значительного ( $<<0,05)$ увеличения содержания в почве обменных форм кальция (в 4,4 раза) и магния (в 10,8 раза), а также существенного сужения соотношения $\mathrm{Ca} / \mathrm{Mg}$ в сторону последнего $(46,48)$. Эти факты, безусловно, имеют положительное значение не только для кислотного режима почвы, но и для ее гранулометрического состава, поскольку взаимодействие магния с органическим веществом активнее способствует образованию в почве Mg-гуматных микроагрегатов $(1,7)$.

На фоне сохранения содержания гумусовых веществ применение цеолита вызывало увеличение в почве количества подвижных соединений фосфора на 22-43 \% и обменных соединений калия на 27-46 \% в зависимости от дозы мелиоранта $(\mathrm{p}<0,05)$.

Согласно современным исследованиям, соединения кремния необходимы культурным растениям как в питании (16-18), так и в обеспечении физиологической защиты от стрессовых факторов агроэкотопа $(15,30,36)$. В связи с этим содержание кремния и его различных фракций в биомассе - значимые критерии при оценке реализации биологического потенциала агрофитоценоза и формирования адаптации $(38,44,56)$.

Прежде всего нужно отметить, что в побочной части урожая растений всех видов в целом накапливалось больше соединений кремния ( $\mathrm{Si}_{\text {общ. }}$ ), чем в основной части, за исключением картофеля: у этой культуры содержание элемента в клубнях было выше, чем в ботве (табл. 3). В то же время применение цеолита в наименьшей степени способствовало повышению содержания кремния именно в фитомассе картофеля, статистически значимо $(\mathrm{p}<0,05)$ увеличивая накопление Siобщ. в клубнях на 4-7 \% и в ботве на 8-11\%, органически связанной формы (Siорг.) - соответственно на 17-26 и 30-44 \%, растворимых минеральных форм $\left(\mathrm{Si}_{\text {мин. }}\right)$ - на 14-18 и 16-19\% в зависимости от дозы породы.

В отношении остальных культур была выявлена повышенная эф- 
фективность в поглощении кремния при внесении цеолита. В частности, в зерновой части урожая озимой и яровой пшеницы содержание Siopг. увеличивалось соответственно на 22-78 и $122 \%$, озимой ржи - на 33-113\%, ячменя - на 95-214 \% по отношению к контрольным значениям. В зерне гороха на фоне внесения в почву породы количество Siopг. увеличивалось в 4-7 раз (р < 0,05), что, вероятно, обусловлено его физиологическими особенностями: наряду со всеми злаковыми ячмень, а также горох и картофель относят к кремнефильным растениям $(19,21,25)$.

Содержание в фитомассе растений минеральных растворимых форм кремния, представляющих собой мономеры ортокремниевой кислоты и метасиликаты, также увеличивалось при удобрении почвы цеолитом, причем в большей мере в соломистой части урожая, чем в зерне. Наилучшей и статистически обоснованной отзывчивостью в накоплении минеральных соединений кремния характеризовалось зерно озимой ржи и озимой пшеницы, ячменя и гороха: на фоне внесения 12 т/га породы содержание

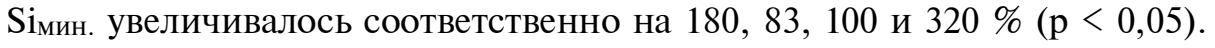

3. Биоаккумуляция различных форм кремния у сортов сельскохозяйственных культур (ОЧ/ПЧ) при применении цеолита Хотынецкого месторождения в разных дозах (ООО «Элитхоз», д. Филипповское, Борской муниципальный р-н, Нижегородская обл.)

\begin{tabular}{|c|c|c|c|c|c|c|}
\hline \multirow[b]{3}{*}{ Вариант } & \multicolumn{6}{|c|}{ Культура } \\
\hline & \multicolumn{2}{|c|}{2015 год } & \multicolumn{2}{|r|}{2016 год } & \multicolumn{2}{|c|}{2017 год } \\
\hline & $\begin{array}{l}\text { озимая пшеница } \\
\text { (Московская 39) }\end{array}$ & $\begin{array}{l}\text { картофель } \\
\text { (Ред Скарлет) }\end{array}$ & $\begin{array}{l}\text { ячмень } \\
\text { (Велес) }\end{array}$ & $\begin{array}{l}\text { яровая пшеница } \\
\text { (Курская 2038) }\end{array}$ & $\begin{array}{l}\text { горох посевной } \\
\text { (Чишминский } \\
95)\end{array}$ & $\begin{array}{l}\text { озимая рожь } \\
\text { (Валдай) }\end{array}$ \\
\hline \multicolumn{7}{|c|}{ О бщ и е с о е д и н е н и я к р е м н и я (Siобщ.), \% на абс. сухую массу } \\
\hline Контроль & $0,23 / 1,18$ & & $0,41 / 1,53$ & $0,19 / 1,03$ & $0,08 / 0,90$ & 42 \\
\hline г/га & 1,22 & 78 & 1,69 & & ,11 & \\
\hline Ц2, 6 т/га & $0,29 / 1,30$ & $3,29 / 1,81$ & $9 / 1,75$ & 0,29 & $0,26 / 1,17$ & \\
\hline т/га & $0,34 / 1,44$ & $3,37 / 1,85$ & $0,95 / 1,79$ & $0,34 / 1,26$ & $0,29 / 1,19$ & \\
\hline \multicolumn{7}{|c|}{ Органически е соединения кремния (Siopг.), \% на абс. сухую массу } \\
\hline Контроль & $0,09 / 0,50$ & $0,70 / 0,50$ & $0,21 / 0,92$ & $0,09 / 0,52$ & $0,01 / 0,23$ & $0,15 / 0,78$ \\
\hline Ц1, 3 т/га & 59 & 59 & $0,41 / 1,28$ & $0,11 /($ & $/ 0,32$ & 02 \\
\hline Ц2, 6 т/га & 0,68 & 5 & $/ 1,38$ & 0 , & 0,37 & 4 \\
\hline Ц3, 12 т/га & $0,16 / 0,84$ & $0,88 / 0,72$ & $0,66 / 1,47$ & 0,2 & $0,07 / 0,42$ & \\
\hline \multicolumn{7}{|c|}{ Растворимы е минеральны е соединения к } \\
\hline Контроль & $0,06 / 0,20$ & $1,30 / 0,32$ & $0,13 / 0,26$ & 0,0 & 0,19 & 0 , \\
\hline г/га & $0 / 0,22$ & 6 & $0,16 / 0,29$ & 0,05 & $/ 0,23$ & 0,0 \\
\hline /га & $/ 0,24$ & 37 & $0,20 / 0,30$ & 0,0 & 0,25 & 0 , \\
\hline Ц3, 12 т/га & $0,11 / 0,25$ & $1,53 / 0,38$ & $0,26 / 0,30$ & $0,06 / 0,15$ & $0,21 / 0,27$ & 0 , \\
\hline \multicolumn{7}{|c|}{ Нерастворимые полимерные соединения } \\
\hline Контроль & $0,08 / 0,48$ & $1,16 / 0,85$ & $0,07 / 0,35$ & $0,06 / 0,40$ & $0,02 / 0,48$ & $0,10 / 0,48$ \\
\hline Ц1, 3 т/га & $/ 0,41$ & $1,04 / 0,83$ & $0,11 / 0,12$ & $0,05 / 0,35$ & 10,56 & $0,07 / 0,29$ \\
\hline га & & & 0,07 & & 55 & \\
\hline Ц3, 12 т/га & $0,07 / 0,35$ & $0,96 / 0,75$ & $0,03 / 0,02$ & $0,08 / 0,30$ & $0,01 / 0,50$ & $0,02 / 0,13$ \\
\hline \multicolumn{7}{|c|}{ 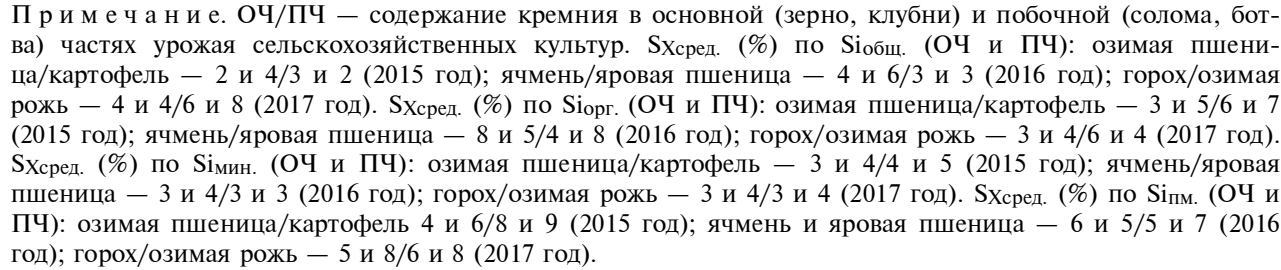 } \\
\hline
\end{tabular}

Накопление органических и минеральных форм кремния в побочной части урожая также повышалось под действием высоких доз цеолита. В наибольшей степени количество Siорг. увеличивалось в соломе

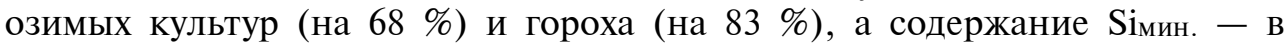
соломе яровой пшеницы (на $36 \%$ ), озимой ржи (на $38 \%$ ) и гороха (на $42 \%)(\mathrm{p}<0,05)$.

Содержание в фитомассе растений нерастворимой фракции крем- 
ниевых соединений ( $\left.\mathrm{Si}_{\text {пм. }}\right)$, представленной поликремниевыми кислотами, аморфным кремнеземом и опаловыми микроагрегатами в фитолитах, в вариантах с применением цеолитовой породы, как правило, соответствовало контрольным значениям или статистически значимо $(\mathrm{p}<0,05)$ уменьшалось. Это явление, несомненно, заслуживает отдельного изучения и имеет ценность как с точки зрения физиологии растений, так и агрономического качества урожая. Лишь в зерне ячменя, яровой пшеницы и гороха, а также в его соломе было выявлено некоторое превышение количества нерастворимых форм кремния вне зависимости от дозы цеолита.

Оценивая общее соотношение накопления органических и минеральных форм кремния в фитомассе растений, нужно подчеркнуть, что применение цеолита способствовало большему увеличению доли органически связанного кремния в соломе зерновых культур и ботве картофеля, чем в зерне и клубнях (исключение - культура гороха). Доля минеральных растворимых кремниевых соединений под действием цеолита повышалась в зерновой (клубневой) части урожая, за исключением ячменя. При этом в зависимости от дозы породы увеличение доли Siорг. от общего количество кремния в фитомассе было более выражено и прослеживалось,

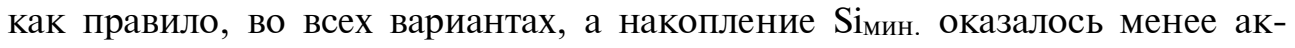
тивным и проявлялось только в варианте Ц1. Эти закономерности свидетельствуют о постепенном связывании силикат-ионов органическими веществами клетки в течение вегетации растений $(18,21)$.

Анализируя урожайность растений под действием высоких доз цеолита (рис.), нужно отметить наличие весьма существенного положительного изменения показателей по всем культурам и в первую очередь у растения-кремнефила ячменя. Биомасса зерна этой культуры возрастала на $32 \%$ при внесении в почву 12 т/га породы, а в варианте с минимальной дозой (3 т/га) показатель повышался на 17 \% относительно контроля $(\mathrm{p}<0,05)$. Примерно одинаковой отзывчивостью на внесение кремнийсодержащего материала в почву характеризовалась урожайность зерна озимой пшеницы в 2015 году и гороха посевного в 2017 году. Показатель повышался соответственно на 4 и $6 \%$ в варианте с минимальной дозой породы и на 8 и $15 \%(\mathrm{p}<0,05)$ - в варианте Цз. Биомасса соломистой части урожая также увеличивалась на фоне высококремнистого материала, но в 1,5-2,0 раза слабее, чем основной части: в среднем по вариантам на $6 \%$ у гороха и на $19 \%(\mathrm{p}<0,05)-$ у ячменя относительно контроля. У озимой пшеницы биомасса соломы, напротив, активнее отзывалась при внесении в почву цеолита: в среднем по вариантам на $20 \%(\mathrm{p}<0,05)$.

В целом по опытам необходимо отметить, что отзывчивость разных частей урожая при внесении породы отчасти зависела от культуры. Так, если в 2015 и 2016 годах статистически обоснованная эффективность действия цеолита на урожайность ботвы картофеля и соломы яровой пшеницы была примерно одинаковой (для картофеля соответственно от 13 и $16 \%$ в варианте Ц1 до 35 и $40 \%$ в варианте Ц3, для пшеницы от 3 и $5 \%$ в варианте Ц1 до 31 и $34 \%$ в варианте Ц3), то в 2017 году при выращивании озимой ржи эффективность действия породы оказалась более выражена в отношении зерновой части урожая (в варианте Цз $14 \%$ достоверной прибавки в массе зерна против $6 \%$ прибавки в массе соломы). В целом по зерновым культурам наилучшая и достоверная $(\mathrm{p}<0,05)$ эффективность отмечалась при внесении в почву 6 т/га цеолита (Ц2), а по картофелю и яровой пшенице -12 т/га (Ц3). 


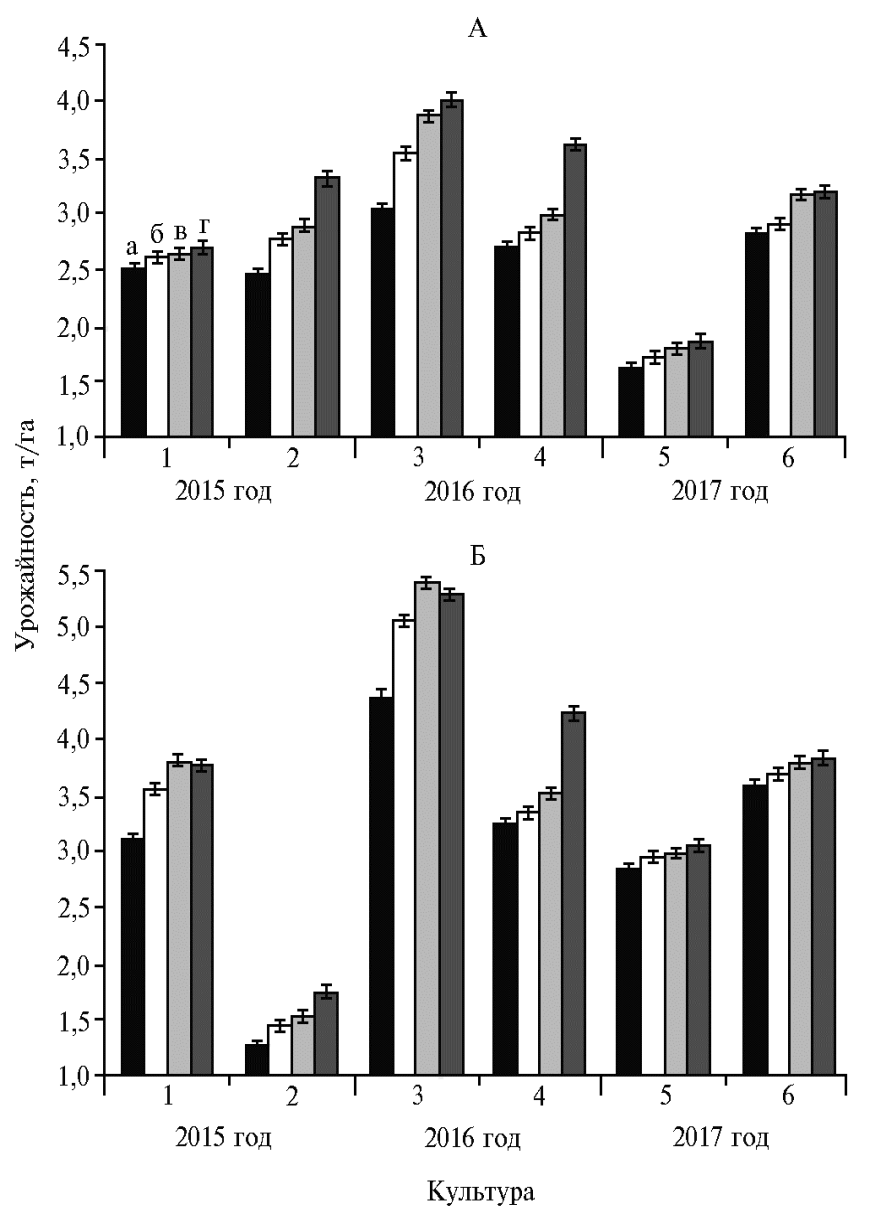

Основная (зерно, клубни) (А) и побочная (солома, ботва) (Б) части урожая озимой пшеницы Triticum aestivum L. сорта Московская 39 (1), картофеля Solarium tuberosum L. сорта Ред Скарлет $(\times 10)(2)$, ячменя Hordeum vulgare L. сорта Велес (3), яровой пшеницы сорта Курская 2038 (4), гороха посевного Pisum sativum L. сорта Чишминский 95 (5), озимой ржи Secale cereale L. сорта Валдай (6) при применении цеолита Хотынецкого месторождения в разных дозах: а контроль, б - 3 т/га, в - 6 т/га, г - 12 т/га (OOO «Элитхоз», д. Филипповское, Борской муниципальный р-н, Нижегородская обл.). $F f$ (основная часть урожая ОЧ и побочная часть урожая ПЧ): озимая пшеница/картофель - 0,97 и 35,50/11,50 и 9,77 (2015 год); ячмень/яровая пшеница - 17,97 и 11,93/48,62 и 36,42 (2016 год); горох/озимая рожь - 12,35 и $3,10 / 11,73$ и 3,19 (2017 год). Теоретический критерий Фишера $(F t)$ при $n l=3$ и р $<0,05-3,86$.

Изменение показателей качества основной продукции культурных растений служит не только критерием агрономической эффективности применения удобрений $(1,16)$, но также отражает состояние агробиогеоценоза и позволяет оценить реализацию агробиологического потенциала культуры или сорта в конкретных почвенно-климатических условиях выращивания $(3,5)$.

Мы установили, что содержание сырой клейковины достоверно $(\mathrm{p}<0,05)$ возрастало в варианте Цз в зерне озимой пшеницы на 5 \% и в вариантах Ц1, Ц2 и Цз в зерне яровой пшеницы соответственно на 9, 14 и $15 \%$ (табл. 4). Наибольшее и статистически обоснованное $(\mathrm{p}<0,05)$ накопление белка в основной части урожая гороха посевного было выявлено при внесении в почву 12 т/га породы (увеличение на $16 \%$ ), а в зерне ячменя - почти в равной степени при внесении 6 и 12 т/га (на 15-20\%).

Статистически значимое ( $p<0,05)$ повышение содержания крахмала в клубнях картофеля и накопления в них витамина С было установлено 
в вариантах Ц2 и Ц3 - соответственно на 5-11 \% по крахмалу и на 19$31 \%$ по аскорбиновой кислоте. На фоне минимальной дозы высококремнистого материала (3 т/га) в основном прослеживались тенденции в оптимизации показателей качества товарной части урожая культур. По-видимому, именно высокие концентрации моно- и поликремниевых кислот в почвенном растворе, которые могут быть обусловлены дозами мелиоранта в 6-12 т/га, создают оптимальный фон для питания и устойчивости агрофитоценоза, что выражается в реализации сорта (в повышении показателей качества) $(7,28,56)$.

4. Показатели качества основной части урожая сельскохозяйственных культур при применении цеолита Хотынецкого месторождения в разных дозах $(M \pm \mathrm{SD}$; ООО «Элитхоз», д. Филипповское, Борской муниципальный p-н, Нижегородская обл., 2015-2017 годы)

\begin{tabular}{|c|c|c|c|c|c|c|}
\hline \multirow{3}{*}{ Вариант } & \multirow{2}{*}{\multicolumn{2}{|c|}{$\begin{array}{c}\text { Клейковина, \% } \\
\text { пшеница }\end{array}$}} & \multicolumn{2}{|r|}{ Белок, \% } & \multirow{3}{*}{\begin{tabular}{|l|}
\multicolumn{1}{|c|}{ Крахмал, \% } \\
картофель \\
(Ред Скарлет)
\end{tabular}} & \multirow{3}{*}{ 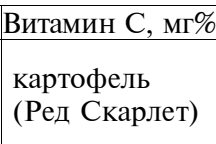 } \\
\hline & & & \multirow{2}{*}{ ячмень } & \multirow{2}{*}{$\begin{array}{l}\text { горох посевной } \\
\text { (Чишминский 95) }\end{array}$} & & \\
\hline & $\begin{array}{l}\text { озимая (Мос- } \\
\text { ковская 39) }\end{array}$ & $\begin{array}{l}\text { яровая (Кур- } \\
\text { ская 2038) }\end{array}$ & & & & \\
\hline Контроль & $33,7 \pm 0,3$ & $27,1 \pm 0,4$ & $10,6 \pm 0,1$ & $17,8 \pm 0,2$ & $14,7 \pm 0,2$ & $17,0 \pm 0,1$ \\
\hline Ц1, 3 т/га & $34,0 \pm 0,1$ & $29,4 \pm 0,2$ & $11,9 \pm 0,2$ & $18,9 \pm 0,3$ & $15,0 \pm 0,2$ & $19,6 \pm 0,1$ \\
\hline Ц2, 6 т/га & $34,9 \pm 0,3$ & $30,8 \pm 0,3$ & $12,2 \pm 0,2$ & $19,4 \pm 0,5$ & $15,5 \pm 0,1$ & $20,3 \pm 0,3$ \\
\hline Ц3, 12 т/га & $35,3 \pm 0,2$ & $31,1 \pm 0,2$ & $12,7 \pm 0,1$ & $20,6 \pm 0,3$ & $16,3 \pm 0,3$ & $22,2 \pm 0,4$ \\
\hline $\mathrm{HCP}_{05}$ & 1,1 & 1,7 & 1,5 & 1,4 & 0,6 & 2,8 \\
\hline
\end{tabular}

В нашей работе применение цеолита в высоких дозах достоверно $(\mathrm{p}<0,05)$ способствовало оптимизации большинства рассмотренных показателей физико-химического состояния почвы и минерального питания культурных растений, в том числе за счет пополнения почвенного поглощающего комплекса обменными соединениями кальция и магния, а мобильного питательного фонда пахотного горизонта - подвижными соединениями фосфора, калия и кремния. В свою очередь, это повышало устойчивость агрофитоценоза к факторам окружающей среды, поскольку выражалось не только в увеличении общей продуктивности урожая, но и в улучшении показателей качества его основной части.

В ряде исследований других авторов применение кремнийсодержащих материалов схожим образом способствовало увеличению продуктивности культур. В частности, в работе Н.Г. Васильевой (7) использование цеолитсодержащего трепела в дозе 1,5 т/га на дерново-подзолистой почве приводило к увеличению урожайности ячменя на 0,8-2,4 ц/га в зависимости от года исследования, что составляло 6-12 \% от контрольных значений. Эффективность влияния материала на продуктивность картофеля достигала 27,5-53,8 ц/га (35-39 \% относительно контроля). Также в совместных исследованиях российских и китайских ученых (56) в условиях провинции Хунань (Китай) на рисовых почвах, сформированных на аллювиальных суглинках, достоверная $(\mathrm{p}<0,05)$ прибавка урожайности зерна риса (Oryza sativa L.) от применения кремниевых удобрений coставляла от 0,95 до 14,9 т/га. Эти удобрения представляли собой аморфный мелкодисперсный диоксид кремния, а также кремнийорганическое удобрение с высоким содержанием не только доступного для растений кремния, но и органического вещества. Полученные результаты подтверждают позитивное действие чистых кремниевых препаратов на продуктивность агрофитоценозов.

В то же время совместное применение высококремнистых материалов и полного минерального удобрения может оказывать более существенное влияние на продуктивность растений. Так, Б.П. Лобода с соавт. (41) 
изучали влияние цеолита Хотынецкого месторождения и NPK-удобрений на урожайность различных сортов картофеля в аналогичных с нашими почвенных условиях. В варианте с максимальной из изученных доз цеолита $\left(1,2\right.$ т/га) на фоне полного минерального удобрения $\left(\mathrm{N}_{90} \mathrm{P}_{60} \mathrm{~K}_{120}\right)$ эффективность совместного действия удобрений варьировала от 14,3 т/га (47 \%) до 22,9 т/га (68 \%) по отношению к контролю в зависимости от сорта культуры и погодных условий года выращивания. Несмотря на относительно низкую дозу цеолита, его сочетание с макроудобрениями способствовало более существенному увеличению урожайности клубней культуры.

Таким образом, при внесении высоких доз цеолитовой породы соединения кремния активнее $(\mathrm{p}<0,05)$ усваиваются сельскохозяйственными культурами из почвы. Этот физиологический процесс активизируется посредством пополнения почвенного раствора легкоподвижными формами не только кремния, но также кальция, магния и других элементов, необходимых для роста и развития растений. В условиях микрополевого опыта, заложенного на дерново-подзолистой легкосуглинистой почве, применение цеолита способствовало повышению реализации агробиологического потенциала районированных сортов озимой и яровой пшеницы, озимой ржи, ячменя, гороха посевного и картофеля, статистически значимо $(\mathrm{p}<0,05)$ увеличивая их урожайность и улучшая наиболее значимые качественные характеристики. Взаимодействие цеолитовой породы с почвой приводило к существенному и достоверному снижению ее кислотности, повышению содержания обменных соединений кальция и магния, а также основных биогенных элементов. Использование цеолита активировало усвоение растениями кремния из почвы и его аккумулирование в фитомассе в виде минеральных растворимых веществ и кремнийорганических компонентов. Установленные закономерности позволяют рассматривать цеолит как альтернативный поликомпонентный мелиоративный материал, обладающий положительным пролонгированным действием на систему почва-растение, и рекомендовать его к исследованию в производственных условиях на почвах подзолистого ряда.

\section{Л И Т Е Р А Т У Р А}

1. Соколов О.А., Черников В.А., Шмырева Н.Я. Эколого-физиологическая оценка минерального питания растений. Известия ТСXА, 2016, 3: 5-17.

2. Baldock J.A., Skjemstad J.O. Role of the soil matrix and minerals in protecting natural organic materials against biological attack. Organic Geochemistry, 2000, 31(7-8): 697-710 (doi: 10.1016/S0146-6380(00)00049-8).

3. Усков И.Б., Якушев В.П., Чесноков Ю.В. Управление агробиологическими системами физико-агрономические и генетико-селекционные аспекты (к 85-летию Агрофизического научно-исследовательского института). Сельскохозяйственная биология, 2017, 52(3): 429-436 (doi: 10.15389/agrobiology.2017.3.429rus).

4. Arshad M.A., Martin S. Identifying critical limits for soil indicators in agroecosystems. Agriculture, Ecosystems and Environment, 2002, 88(2): 153-160 (doi: 10.1016/S0167-8809(01)00252-3).

5. Михайленко И.М. Новые направления моделирования в сельскохозяйственной биологии. Агрофизика, 2011, 1(1): 44-53.

6. Рыбась И.А. Повышение адаптивности в селекции зерновых культур (обзор). Сельскохозяйственная биология, 2016, 51(5): 617-626 (doi: 10.15389/agrobiology.2016.5.617rus).

7. Васильева Н.Г. Оценка эффективности трепела как почвенного мелиоранта. Проблемы агрохимии и экологии, 2017, 3: 24-30.

8. Harley A.D., Gilkes R.J. Factors influencing the release of plant nutrient elements from silicate rock powders: a geochemical overview. Nutrient Cycling in Agroecosystems, 2000, 56(1): 11-36 (doi: 10.1023/A:1009859309453).

9. Matichenkov V.V., Wei X., Liu D., Bocharnikova E.A. Theory, practice and prospection of Si fertilizer. Agricultural Science Technology, 2013, 14(3): 498-502.

10. Самсонова Н.Е. Роль кремния в формировании фосфатного режима дерновоподзолистых почв. Агрохимия, 2005, 8: 11-18. 
11. Agafonov E.V., Khovanskii M.V. Effect of bentonite on the fertility of an ordinary chernozem. Eurasian Soil Science, 2014, 47(5): 478-482 (doi: 10.1134/S1064229314050020).

12. Cornelis J.T., Delvaux B., Georg R.B., Lucas Y., Ranger J., Opfergelt S. Tracing the origin of dissolved silicon transferred from various soil-plant systems towards rivers: a review. Biogeosciences, 2011, 8(1): 89-112 (doi: 10.5194/bg-8-89-2011).

13. Медведев С.С. Физиология растений. СПб, 2015.

14. Epstein E. Silicon: its manifold roles in plants. Annals of Applied Biology, 2009, 155(2): 155-160 (doi: 10.1111/j.1744-7348.2009.00343.x).

15. Liang Y., Sun W., Zhu Y-G., Christie P. Mechanisms of silicon-mediated alleviation of abiotic stresses in higher plants: a review. Environmental Pollution, 2007, 147(2): 422-428 (doi: 10.1016/j.envpol.2006.06.008).

16. Самсонова Н.Е. Кремний в растительных и животных организмах. Агрохимия, 2019, 1: 86-96 (doi: 10.1134/S0002188119010071).

17. Artyszak A. Effect of silicon fertilization on crop yield quantity and quality - a literature review in Europe. Plants, 2018, 7(54): 1-17 (doi: 10.3390/plants7030054).

18. Tubana B.S., Babu T., Datnoff L.E. A review of silicon in soils and plants and its role in US agriculture: history and future perspectives. Soil Science, 2016, 181(9/10): 393-411 (doi: 10.1097/SS.0000000000000179).

19. Матыченков В.В. Роль подвижных соединений кремния в растениях и в системе почварастение. Докт. дис. Пущино, 2008.

20. Hodson M.J., White P.J., Mead A., Broadley M.R. Phylogenetic variation in the silicon composition of plants. Annals of Botany, 2005, 96: 1027-1046 (doi: 10.1093/aob/mci255).

21. Колесников М.П. Формы кремния в растениях. Успехи биологической химии, 2001, 41: 301-322.

22. Ma J.F., Yamaji N. Silicon uptake and accumulation in higher plants. Trends in Plant Science, 2006, 11(8): 392-397 (doi: 10.1016/j.tplants.2006.06.007).

23. Козлов Ю.В. Эффективность соединений кремния при возделывании зерновых культур в условиях Смоленской области. Автореф. канд. дис. М., 2010.

24. Панова Г.Г., Аникина Л.М., Канаш Е.В., Удалова О.Р., Шибанов Д.В. Кремнийсодержащие хелатные микроудобрения в повышении устойчивости растений к действию стрессовых факторов. Агрофизика, 2012, 3(7): 31-40.

25. Biel K.Y., Matichenkov V.V., Fomina I.R. Protective role of silicon in living systems. In: Functional foods for chronic diseases. Advances in the development of functional foods. Vol. 3 /D.M. Martirosyan (ed.). D\&A lnc., Richardson, 2008: 208-231.

26. Капранов В.Н. Влияние кремния на структуру, прочность и урожайность озимой тритикале. Агрохимический вестник, 2008, 2: 32-34.

27. Mitani-Ueno N., Yamaji N., Ma J.F. Silicon efflux transporters isolated from two pumpkin cultivars contrasting in Si uptake. Plant Signaling \& Behavior, 2011, 6(7): 991-994 (doi: $10.4161 /$ psb.6.7.15462).

28. Курносова Т.Л., Осипова Л.В., Верниченко И.В., Быковская И.А., Яковлев П.А. Формирование продуктивности растений пшеницы (Triticum aestivum L.) и тритикале (×Triticosecale Wittm. \& A. Camus) на фоне предпосевной обработки семян селеном, кремнием и цинком в условиях окислительного стресса, вызванного засухой. Проблемы агрохимии $и$ экологии, 2017, 3: 13-23.

29. Gong H.J., Chen K.M., Zhao Z.G., Chen G.C., Zhou W.J. Effect of silicon on defense of wheat against oxidative stress under drought at different development stages. Biologia Plantarum, 2008, 52(3): 592-596.

30. Tale Ahmad S., Haddad R. Study of silicon effects on antioxidant enzyme activities and osmotic adjustment of wheat under drought stress. Czech Journal of Genetics and Plant Breeding, 2011, 47(1): 17-27.

31. Ma J.F. Silicon transporters in higher plants. In: MIPS and their role in the exchange of metalloids. Advances in experimental medicine and biology, vol. 679 /T.P. Jahn, G.P. Bienert (eds.). Springer, New York, NY, 2010: 99-109 (doi: 10.1007/978-1-4419-6315-4 8).

32. Акимова С.В., Раджабов А.К., Бухтин Д.А., Трофимова М.С. Влияние биологически активных веществ кремнийорганической природы на укореняемость и дальнейшее развитие одревесневших и зеленых черенков винограда межвидового происхождения. Известия ТСХА, 2015, 4: 36-48.

33. Зейслер Н.А. Влияние силатранов на прорастание семян хлебных злаков. Интеллектуальный потенциал XXI: ступени познания, 2016, 31: 6-10.

34. Hernandez-Apaolaza L. Can silicon partially alleviate micronutrient deficiency in plants? A review. Planta, 2014, 240(3): 447-458 (doi: 10.1007/s00425-014-2119-x).

35. Самсонова Н.Е., Капустина М.В., Зайцева З.Ф. Влияние соединений кремния и минеральных удобрений на урожайность яровых зерновых культур и содержание в них антиоксидантных ферментов. Агрохимия, 2013, 10: 66-74.

36. Pirzad A., Mohammadzadeh S. Zeolite use efficiency variation under water deficit stress in grass pea and lentil. Журнал Сибирского федерального университета. Серия: Биология, 2016, 9(3): 291-303 (doi: 10.17516/1997-1389-2016-9-3-291-303). 
37. Wang X., Ou-yang C., Fan Z., Gao S., Chen F., Tang L. Effects of exogenous silicon on seed germination and antioxidant enzyme activities of Momordica charantia under salt stress. Journal of Animal \& Plant Sciences, 2010, 6: 700-708.

38. Пашкевич Е.Б., Кирюшин Е.П. Роль кремния в питании растений и в защите сельскохозяйственных культур от фитопатогенов. Проблемы агрохимии и экологии, 2008, 2: 52-57.

39. Fauteux F., Rémus-Borel W., Menzies J.G., Bélanger R. Silicon and plant disease resistance against pathogenic fungi. FEMS Microbiology Letters, 2005, 249(1): 1-6 (doi: 10.1016/j.femsle.2005.06.034).

40. Mitani N., Yamaji N., Ma J.F. Identification of maize silicon influx transporters. Plant and Cell Physiology, 2009, 50: 5-12 (doi: 10.1093/pcp/pcn110).

41. Лобода Б.П., Багдасаров В.Р., Фицуро Д.Д. Влияние удобрения на основе цеолитсодержащих трепелов Хотынецкого месторождения на урожайность и качество картофеля. Аحрохимия, 2014, 3: 28-35.

42. Chimney M.J., Wan Y., Matichenkov V.V., Calvert D.V. Minimizing phosphorus release from newly flooded organic soils amended with calcium silicate slag: a pilot study. Wetlands Ecology and Management, 2007, 15(5): 385-390 (doi: 10.1007/s11273-007-9037-7).

43. Ma J., Tamai K., Yamaji N., Mitani N., Konishi S., Katsuhara M., Ishiguro M., Murata Y., Yano M. A silicon transporter in rice. Nature, 2006, 440: 688-691 (doi: 10.1038/nature04590).

44. Perry C.C., Keeling-Tucker T. Biosilicification: the role of the organic matrix in structure control. J. Biol. Inorg. Chem., 2000, 5: 537-550 (doi: 10.1007/s007750000130).

45. Bocharnikova E.A., Matichenkov V.V. Influence of plant association on the silicon cycle in the soil-plant system. Applied Ecology and Environmental Research, 2012, 10(4): 547-560 (doi: 10.15666/aeer/1004 547560).

46. Сычев В.Г., Аканова Н.А. Современные проблемы и перспективы химической мелиорации кислых почв. Плодородие, 2019, 1(106): 3-7 (doi: 10.25680/S19948603.2019.106.01).

47. Кузьменко Н.Н. Влияние известкования на показатели плодородия дерново-подзолистой легкосуглинистой почвы. Агрохимия, 2019, 10: 35-38 (doi: 10.1134/S0002188119100090).

48. Окорков В.В. К теории химической мелиорации кислых почв. Агрохимия, 2019, 9: 3-17 (doi: 10.1134/S0002188119090096).

49. Шабина И.С., Вилков В.С., Кузнецова Л.П. Характеристики основных сортов сельскохозяйственных культур, рекомендованных для возделывания в Волго-Вятском регионе. Нижний Новгород, 2010.

50. Доспехов Б.А. Методика полевого опыта (с основами статистической обработки результатов исследований). М., 2011.

51. Кусова Н.В., Степанова Л.П. Кипящие камни (цеолиты). Орел, 2005.

52. Минеев В.Г. Практикум по агрохимии. М., 2001.

53. ФР.1.31.2011.09380. Продукты пищевые и сырье продовольственное. Методика измерений массовой доли витамина С флуориметрическим методом на анализаторе жидкости «Флюоpam-02» (М 04-07-2010). СПб, 2010.

54. Матыченков И.В., Хомяков Д.М., Пахненко Е.П., Бочарникова Е.А., Матыченков В.В. Подвижные кремниевые соединения в системе почва-растение и методы их определения. Вестник Московского университета. Серия 17: Почвоведение, 2016, 3: 37-46.

55. Мамонтов В.Г., Гладков А.А. Практикум по химии почв. М., 2015.

56. Дан-дан 3., Пенг-бо 3., Бочарникова Е.А., Матыченков В.В., Хомяков Д.М., Пахненко Е.П. Оценка объемов связывания углерода корнями риса под влиянием кремниевых удобрений. Вестник Московского университета. Серия 17: Почвоведение, 2019, 3: 17-22.

1ФГБОУ ВО Нижегородский государственный педагогический университет им. Козьмы Минина, Поступила в редакцию 603005 Россия, г. Нижний Новгород, ул. Ульянова, 1, e-mail: a_v_kozlov@mail.ru $₫$, uromova2012@yandex.ru; 2ФГБОУ ВО Ульяновский государственный аграрный университет им. П.А. Столыпина, 432017 Россия, г. Ульяновск, бульвар Новый Венец, 1, e-mail: agroec@yandex.ru

Sel'skokhozyaistvennaya biologiya [Agricultural Biology], 2021, V. 56, № 1, pp. 183-198

\title{
MOBILITY OF SILICON, FERTILITY OF SOD-PODZOLIC SOIL, BIOACCUMULATION OF SILICON AND YIELDS OF AGRICULTURAL CROPS UNDER THE INFLUENCE OF ZEOLITE
}

\author{
A.V. Kozlov ${ }^{\boxplus}$, A.H. Kulikova ${ }^{2}$, I.P. Uromova ${ }^{1}$
}

${ }^{1}$ Minin Nizhny Novgorod State Pedagogical University, 1, ul. Ulyanova, Nizhny Novgorod, 603950 Russia, e-mail a_v_kozlov@mail.ru (corresponding author $\bowtie$ ), uromova2012@yandex.ru; 
2Stolypin Ulyanovsk State Agricultural University, 1, bulv. Noviy Venets, Ulyanovsk, 432017 Russia, e-mail agroec@yandex.ru

ORCID:

Kozlov A.V. orcid.org/0000-0003-3034-6566

Kulikova A.H. orcid.org/0000-0002-7327-3742

Uromova I.P. orcid.org/0000-0003-1000-3603

The authors declare no conflict of interests

Received January 19, 2020

doi: 10.15389/agrobiology.2021.1.183eng

Abstract

In modern arable farming, beneficial properties of silicon-containing natural materials are of interest, including zeolites which have a structuring and moisture-retaining effect on soil, can optimize conditions for development of agronomically valuable microorganisms, replenish soil solution with available forms of potassium, phosphorus and trace elements, and show activity towards excessive acidity of soils. The provision of silicon makes it possible to increase adaptation of crops to stresses caused by agroecotope factors, leading to an increase in productivity and yield quality characteristics. For the first time, in the conditions of sod-podzolic soils of the Nizhny Novgorod region, we established the beneficial influence of various doses of zeolite rock of the Khotynets deposit on the main properties of effective fertility of sod-podzolic light loamy soil and content of biologically active silicon in it. The impact of the rock on accumulation of various silicon compounds in aboveground biomass of crops is evaluated. Increase of their yield due to zeolite action was revealed and optimization of quality indices of the main part of the crop was established. The purpose of the work was to determine mobility of silicon in sod-podzolic light loamy soil, to evaluate its physicochemical and agrochemical properties, and to identify patterns of bioaccumulation of various silicon compounds by above-ground parts of plants depending on the dose of zeolite rock as a high-silicon reclamation material. Studies carried out in 2015-2017 involved crop varieties zoned in the VolgaVyatka region, the winter wheat (Triticum aestivum L.) cv. Moscovskaya 39 and spring wheat cv. Kurskaya 2038, winter rye (Secale cereale L.) cv. Valdai, barley (Hordeum vulgare L.) cv. Veles, peas sown (Pisum sativum L.) cv. Chishminsky 95 and potato (Solarium tuberosum L.) cv. Red Scarlet. The design of the experiment included control (no treatment) and incorporation of 3,6, and $12 \mathrm{t} / \mathrm{ha}$ zeolite of the Khotynetsky deposit (OOO Alsiko-Resurs, Russia) into the soil. The rock was introduced into soil once, manually, in the summer period of 2014. The soil of the field is a sod-podzolic medium-sod shallow-depressed ungelled light-ugly, formed on a cover loam. Plants were harvested upon complete ripeness (grain crops), the beginning (peas) and the end (potatoes) of drying of the tops. In above-ground plant biomass of all crops, the contents of organic, soluble mineral, insoluble polymer and general silicon compounds were determined. Soil was samples on harvest day from five points of each plot by envelope method and the content of mobile silicon compounds was evaluated. Also, in soil samples, the actual, exchange acidity, hydrolytic acidity, the content of exchange compounds of calcium and magnesium, the amount of exchange forms of potassium, the content of mobile phosphorus compounds according to Kirsanov and humus according to Tyurin were measures. It was shown that the use of $12 \mathrm{t} / \mathrm{ha}$ zeolite rock contributes to an increase in the content of watersoluble forms of silicon in the soil by $143 \%$ ( $p<0.05)$, acid-soluble forms by 2 times. The use of reclamation doses of zeolite for three years contributed to a reliable $(p<0.05)$ decrease of exchange soil acidity by $0.5 \mathrm{pH}$, hydrolytic acidity by $0.33 \mathrm{mg}$-eqv/100 g, significant increase of content of exchange compounds of calcium and magnesium (by 4.4 and $10.8 \mathrm{mg}$-eqv/100 g, respectively). In addition, there was a statistically significant $(\mathrm{p}<0.05)$ increase in the amount of mobile phosphorus compounds (by $43 \%$ ) and potassium (by $46 \%$ ) vs. the control values. The accumulation of silicon in plant biomass depended on a crop, and in all tested cereals, it was higher in by-products than in the main yield. The use of zeolite led to an increase in absorption of silicon from soil, especially in silicon accumulators. Under the action of material, in grain of spring wheat, barley and peas accumulation of total silicon exceeded control values 1.8-, 2.3-, and 3.6-fold, respectively $(\mathrm{p}<0.05)$. The use of zeolite activated generation of organic and mineral soluble forms of element in the grain part of crop, but did not contribute to the accumulation of insoluble silicon compounds in the plant biomass. The main yield of winter wheat increased by $0.19 \mathrm{t} / \mathrm{ha}$, of barley by $0.98 \mathrm{t} / \mathrm{ha}$, of sown peas by $0.24 \mathrm{t} / \mathrm{ha}$, of potatoes by $8.6 \mathrm{t} / \mathrm{ha}$, of spring wheat by $0.92 \mathrm{t} / \mathrm{ha}$, and of winter rye by $0.39 \mathrm{t} / \mathrm{ha}(\mathrm{p}<0.05)$. Doses of 6 and $12 \mathrm{t} / \mathrm{ha}$ of zeolite had best effect on all crops, while the ratio of main and by-products narrowed towards grain (tuberous) part of crop. Optimization of silicon nutrition of cultivated plants and mobility of element in soil due to application of high doses of zeolite had a positive effect on quality of the main yield. The accumulation of raw gluten in grain of winter and spring wheat reached 35.3 and $31.1 \%$, respectively, and the grain levels of protein in barley and peas was 12.7 and $20.6 \%$, respectively. Improved quality of potato tubers under the influence of the zeolite was expressed in enrichment with vitamin $\mathrm{C}$ (up to $22.2 \mathrm{mg} \%$ ) and higher accumulation of starch (up to $16.3 \%$ ). Consequently, use of zeolite as a fertilizer and reclamation material was agronomically feasible and necessary under conditions of sod-podzolic soils.

Keywords: silicon, zeolite, crops, efficiency and quality of harvest, bioaccumulation of silicon in biomass, contents and mobility of silicon in soil. 